\title{
Diphenylcyclopropenone-Induced Vitiligo in a Patient with Alopecia Universalis
}

\author{
Hassan Riad Haya Al Mannai Khalid Mansour Khalifa Al Qaatri \\ Sharifa Al Dosari Amina Al Obaidaly Emad Sultan \\ Dermatology Department, Rumailah Hospital, Doha, Qatar
}

\section{Key Words}

Diphenylcyclopropenone $\cdot$ Vitiligo $\cdot$ Alopecia

\begin{abstract}
Alopecia areata and vitiligo are autoimmune diseases, both associated with multiple autoimmune comorbidities. Many studies show colocalization of these diseases at the same anatomical site. Here, we have a case where both disorders were reported to present in the same patient. Diphenylcyclopropenone (diphencyprone, DCP) is used in the treatment of alopecia areata and may induce vitiligo in some patients. We report on one case of vitiligo that was induced by DCP during therapy for alopecia universalis. Alopecia areata and vitiligo share many susceptibility genes. Follicular melanocyte destruction may represent the link between the two diseases.

(c) 2013 S. Karger AG, Basel
\end{abstract}

\section{Introduction}

Alopecia areata is a common skin disease that affects both children and adults, with $10 \%$ of patients presenting with more severe forms of the disease, i.e. alopecia totalis (AT) or alopecia universalis (AU). The lifetime risk of alopecia areata is estimated to be approximately $1.7 \%$. Alopecia areata and its severe forms AT and AU are associated with other autoimmune diseases [1]. Vitiligo also affects both young and adult subjects and is associated with the autoimmune diseases thyroiditis, type I diabetes and alopecia areata. The worldwide prevalence of vitiligo ranges between 0.5 and 2\% [2]. Alopecia and vitiligo share autoimmune etiology. Autoimmune diseases are characterized not only by multiple 
Riad et al.: Diphenylcyclopropenone-Induced Vitiligo in a Patient with Alopecia Universalis

autoimmune comorbidities, but in many instances also overlap and occur simultaneously in the same patient.

The coexistence of alopecia areata and vitiligo in the same patient was well documented more than a century ago [3]. For a patient with alopecia areata, the chance of getting vitiligo is double that of the normal population and is probably higher in patients with AT or AU, while the chance of a vitiligo patient getting alopecia areata is four times that of people without vitiligo. Colocalization of alopecia areata and vitiligo at the same anatomical site is a more complicated story and has been reported on in many studies. Many hypotheses have been suggested; however, it is actually a rare phenomenon [4-12].

During the treatment of patients with alopecia areata, the induction of vitiligo by contact sensitizers using diphenylcyclopropenone (diphencyprone, DCP) has been reported in many articles [13-19]. We report here on a case of DCP-induced vitiligo in a patient with AU.

\section{Case Report}

A 52-year-old, diabetic, white male presented with an 18-year history of generalized hair loss. The patient was diagnosed as having AU. Upon examination, there was a universal loss of hair on the whole scalp, the face, the eyebrows and eyelashes, the arms, the axilla, the moustache and the beard areas. Dermoscopy did not show any cicatrization, but extensive areas of yellow dots and small areas with black dots and fine, small exclamation-mark hairs were noticed. There were no signs of regrowth in any of the affected areas. Nails and mucous membranes were normal. He had a positive family history of alopecia areata, but no family or personal history of vitiligo. Laboratory investigations showed an elevation of antithyroid peroxidase and antinuclear antibody (1:160) speckled pattern. Antiparietal cell antibody and anti-intrinsic-factor antibody were negative. Thyroid function test, homocysteine and vitamin $\mathrm{B}_{12}$ showed normal levels. Before attending our OPD clinic, the patient underwent topical and intralesional steroid therapies at another hospital without improvement. In January 2011, we decided to initiate DCP therapy on the scalp only. Following the classic sensitization regimen, we started with one $2 \%$ application, followed by $0.0001 \%$ after 2 weeks, and then a weekly dose escalation guided by the appearance of erythema and the contact dermatitis reaction. The scalp showed erythema and crusts formation during therapy with no signs of hair regrowth. In July 2011, after 6 months of therapy and when we had reached a concentration of $0.01 \%$, the patient presented with multiple white patches on the occipital and parietal areas of the scalp, diagnosed clinically and by Wood's light examination as vitiligo (fig. 1). We discontinued DCP and from July 2011 to April 2012, we administered a combined therapy of monochromic excimer laser radiation (308 nm; XTRAC, Photomedex, USA) in 3 sessions weekly (total dose $18.3 \mathrm{~J} / \mathrm{cm}^{2}$ ) combined with topical pimecrolimus $1 \%$ cream twice daily. Depigmented areas showed a mild improvement, but this combined therapy had no effect on hair regrowth. The patient discontinued both lines of treatment. In September 2012, we started a low-pulse prednisone therapy, administering 80 mg prednisone per day on weekends ( 2 days of therapy and 5 days off treatment) for 4 months (until January 2013). In conjunction with prednisone, we prescribed topical prostaglandin E2 solution (Latisse: bimatoprost $0.03 \%$ ) for the eyebrows and eyelashes. The hair regrowth was significant. After years, he at last achieved hair regrowth on his scalp, even though the vertex showed a moderate, androgenic, permanent loss of hair. His eyebrows recovered, but his eyelashes showed no response. He also experienced considerable though incomplete repigmentation of areas of skin with vitiligo. Oral pulse prednisone therapy was tapered and then discontinued after 4 months. Potent topical clobetasone 
Riad et al.: Diphenylcyclopropenone-Induced Vitiligo in a Patient with Alopecia Universalis

propionate $0.05 \%$ ointment was applied once daily to the scalp in addition to topical pimecrolimus $1 \%$ cream twice daily to the moustache and beard areas. Topical prostaglandin E2 solution was continued for the eyebrows and eyelashes. The topical therapies were continued for the next 16 weeks (until May 2013). The improvement was satisfactory for the patient, although tiny residual patches of colocalized alopecia and vitiligo can still be seen on the vertex and occipital areas (fig. 2). Regrowth of his facial hair is almost complete, especially his moustache. There has been no relapse and hair growth has continued. A maintenance therapy consisting of a topical weekend application of local agents is being continued with no intention of interruption. A spontaneous regression of both conditions cannot be ruled out.

\section{Discussion}

Studies reporting anatomical colocalization of alopecia areata and vitiligo are displayed in table 1 [5-12]. The female-to-male ratio was 3:1. Age ranged from 9 to 60 years (mean 27.4 years). Fifty percent of the cases were Asian and were mainly from India. One 18-yearold girl was African-American and all other cases were Caucasian. In 1 case, alopecia preceded vitiligo while in another, the reverse happened and vitiligo preceded alopecia. In 2 cases, the two diseases presented simultaneously. Except for 1 case of AT, the alopecia in most reported cases was localized and was confined to limited anatomical sites, i.e. either the scalp or periorbital area (ratio 3:1). Pathological examination confirmed the diagnosis in 7 of 8 reported cases.

Studies describing DCP-induced vitiligo in patients with alopecia areata are displayed in table 2 [13-19]. The male-to-female ratio was 3:2. Age ranged from 12 to 67 years (mean 39.9 years). Race was equally distributed between Asians and Caucasians. Only severe forms of alopecia were reported, which necessitated the use of DCP. The duration of DCP-induced vitiligo varied from 6 weeks to 10.5 months. The DCP concentration varied from 0.0001 to $0.5 \%$, although in most of the cases, depigmentation occurred with a relatively higher concentration of $0.5 \%$. In $75 \%$ of the cases, vitiligo appeared as focal lesions on remote areas or areas adjacent to the DCP application site. Most DCP-induced vitiligo responds well to narrowband ultraviolet B (NB-UVB) therapy. Two studies in the 1990s reported pigmentary changes that were attributed to DCP application for alopecia areata, but the authors did not diagnose the depigmentation as vitiligo and so we decided to exclude these studies from table $2[20,21]$.

A genome-wide association study was performed on 1,054 alopecia areata cases and 3,278 controls; it revealed several susceptibility loci on eight genomic regions. Two regions out of eight shared 4 loci, and had a strong association with alopecia areata as well as being involved in generalized vitiligo. Three of the shared loci were within the human leukocyte antigen region 6p21.32 (HLA-DRA, BTNL2 and C6orf10) and one was in the region 10p15.1 (IL-2RA). These genes, except for C6orf10 (the function of which is unknown), influence the role of the immune system in the pathogenesis of both disorders as antigen presentation, costimulatory signaling and $\mathrm{T}$ cell proliferation [22].

Patients with autoimmune polyendocrinopathy candidiasis-ectodermal dysplasia/autoimmune polyendocrine syndrome type 1 /polyglandular autoimmune syndrome type 1 present with a combination of Addison's disease, hypoparathyroidism, ectodermal dysplasia and/or chronic mucocutaneous candidiasis. They may also have alopecia areata and vitiligo, besides other multiorgan involvement such as gonadal failure, pernicious anemia, chronic active hepatitis, corneal dystrophy and enamel dystrophy [23]. 
Riad et al.: Diphenylcyclopropenone-Induced Vitiligo in a Patient with Alopecia Universalis

Vogt-Koyanagi-Harada syndrome (VKH) is a well-known entity that may link alopecia areata and vitiligo. It is characterized by multisystem autoinflammation against melanocytecontaining tissues. It involves mainly the eyes, ears, meninges and skin. Skin features of VKH are vitiligo, poliosis and alopecia areata, which follow ocular and neurological symptoms. Incomplete forms of the disease may occur involving only one or more organs: the eyes, ears or skin. In many ethnic groups, VKH is associated with the susceptibility allele HLADRB $1 * 0405$ that controls antigen presentation [24].

We would like to conclude that colocalization of vitiligo and alopecia areata is reported in many cases, and vitiligo is also reported to colocalize with other diseases like psoriasis and lichen planus [5]. DCP-induced vitiligo can occur in patients with alopecia areata as well as in patients with other skin diseases like verruca vulgaris [25]. The case presented in this study responded partially to phototherapy by excimer laser, but developed a higher degree of hair regrowth on a short course of pulse systemic steroid therapy. Areas with vitiligo were focal, localized and responded well to therapy. For both conditions, alopecia areata and vitiligo, spontaneous regression cannot be ruled out.

The mechanism of follicular melanocyte destruction in vitiligo and alopecia areata may provide a link between the two diseases. In the context of evolution and regression of alopecia areata, can we consider the appearance of white hairs to be a characteristic unique to vitiligo or is it a feature of the colocalization of vitiligo and alopecia areata?

\section{References}

1 Hordinsky M, Ericson M: Autoimmunity: alopecia areata. J Investig Dermatol Symp Proc 2004;9:73-78.

-2 Krüger C, Schallreuter KU: A review of the worldwide prevalence of vitiligo in children/adolescents and adults. Int J Dermatol 2012;51:1206-1212.

3 Gaskoin G: Alopecia: vitiligo. Br Med J 1873;1:642-643.

4 Klaber R: Vitiligo with associated alopecia areata. Proc R Soc Med 1934;27:1577-1578.

5 Dhar S, Kanwar AJ: Colocalization of vitiligo and alopecia areata. Pediatr Dermatol 1994;11:85-86.

-6 Adams BB, Lucky AW: Colocalization of alopecia areata and vitiligo. Pediatr Dermatol 1999;16:364-366.

7 Cho HR, Lee MH: Colocalisation of segmental vitiligo and alopecia areata. Korean J Dermatol 2007;45:11151117.

8 Yadav S, Dogra S, Kaur I: An unusual anatomical colocalization of alopecia areata and vitiligo in a child, and improvement during treatment with topical prostaglandin E2. Clin Exp Dermatol 2009;34:e1010-e1011.

9 Ramot Y, Thomaidou E, Mali A, Zlotogorski A: An extraordinary colocalization of alopecia areata and vitiligo. Int J Trichology 2010;2:108-109.

10 Rodriguez-Martin M, Merino N, Contreras P, Santana GG, Martin BR, Martin-Herrera A, et al: Anatomical colocalization of vitiligo and alopecia areata. Open Autoimmun J 2010;2:193-196.

-11 Ozcan D, Cevlik Aydoğan F: Concurrence of alopecia areata and vitiligo at the same anatomical site. Australas J Dermatol 2012;53:e61-e63.

-12 Krishnaram AS, Saigal A, Adityan B: Alopecia areata - vitiligo overlap syndrome: an emerging clinical variant. Indian J Dermatol Venereol Leprol 2013;79:535-537.

13 Hatzis J, Gourgiotou K, Tosca A, Stratigos J: Vitiligo as a reaction to topical treatment with diphencyprone. Dermatologica 1988;177:146-148.

14 Duhra P, Foulds IS: Persistent vitiligo induced by diphencyprone. Br J Dermatol 1990;123:415-416.

-15 Henderson CA, Ilchyshyn A: Vitiligo complicating diphencyprone sensitization therapy for alopecia universalis. Br J Dermatol 1995;133:496-497.

16 Pan JY, Theng C, Lee J, Goh BK: Vitiligo as an adverse reaction to topical diphencyprone. Ann Acad Med Singapore 2009;38:276-277.

17 Pires MC, Martins JM, Montealegre F, Gatti FR: Vitiligo after diphencyprone for alopecia areata. Dermatol Res Pract 2010;2010:171265.

18 Ganzetti G, Simonetti O, Campanati A, Giuliodori K, Offidani A: Phototherapy as a useful therapeutic option in the treatment of diphenylcyclopropenone-induced vitiligo. Acta Derm Venereol 2010;90:642-643.

-19 Nilforoushzadeh MA, Keshtmand G, Jaffary F, Kheirkhah A: Diphencyprone-induced vitiligo: a case report. Case Rep Med 2012;2012:356236.

20 Van der Steen P, Happle R: 'Dyschromia in confetti' as a side effect of topical immunotherapy with diphenylcyclopropenone. Arch Dermatol 1992;128:518-520. 
Riad et al.: Diphenylcyclopropenone-Induced Vitiligo in a Patient with Alopecia Universalis

21 Nasca MR, Micali G, Pulvirenti N, Licastro-Cicero R: Transient leucoderma appearing in an untreated area following contact immunotherapy for alopecia areata. Eur J Dermatol 1998;8:125-126.

22 Petukhova L, Duvic M, Hordinsky M, Norris D, Price V, Shimomura Y, Kim H, Singh P, Lee A, Chen WV, Meyer KC, Paus R, Jahoda CA, Amos CI, Gregersen PK, Christiano AM: Genome-wide association study in alopecia areata implicates both innate and adaptive immunity. Nature 2010;466:113-117.

-23 Alikhan A, Felsten LM, Daly M, Petronic-Rosic V: Vitiligo: a comprehensive overview. Part I. Introduction, epidemiology, quality of life, diagnosis, differential diagnosis, associations, histopathology, etiology, and work-up. J Am Acad Dermatol 2011;65:473-491.

24 Greco A, Fusconi M, Gallo A, Turchetta R, Marinelli C, Macri GF, De Virgilio A, de Vincentiis M: VogtKoyanagi-Harada syndrome. Autoimmun Rev 2013;pii:S1568-9972(13)00037-2.

25 Oh YJ, Shin MK, Lee MH: Narrow-band ultraviolet B treatment for diphenylcyclopropenone-induced vitiliginous lesions. Acta Derm Venereol 2012;92:102-103.

Table 1. Published reports on colocalization of alopecia areata and vitiligo in the same anatomical area

\begin{tabular}{|c|c|c|c|c|c|c|}
\hline Author, year & $\begin{array}{l}\text { Sex/ } \\
\text { age }\end{array}$ & $\begin{array}{l}\text { Country/ } \\
\text { race }\end{array}$ & $\begin{array}{l}\text { Duration/ } \\
\text { sequence of vitiligo } \\
\text { and alopecia }\end{array}$ & $\begin{array}{l}\text { Site/ } \\
\text { size }\end{array}$ & $\begin{array}{l}\text { Investigations/ } \\
\text { comorbidity }\end{array}$ & Therapy \\
\hline $\begin{array}{l}\text { Dhar and Kanwar [5], } \\
1994\end{array}$ & $\begin{array}{l}\text { female/ } \\
9 \text { years }\end{array}$ & $\begin{array}{l}\text { India/ } \\
\text { Asian }\end{array}$ & $\begin{array}{l}1 \text { year/ } \\
\text { both at the same time }\end{array}$ & $\begin{array}{l}\text { scalp, occipital area/ } \\
2.5 \mathrm{~cm}\end{array}$ & biopsy & $\mathrm{N} / \mathrm{A}$ \\
\hline $\begin{array}{l}\text { Adams and Lucky [6], } \\
1999\end{array}$ & $\begin{array}{l}\text { female/ } \\
18 \text { years }\end{array}$ & $\begin{array}{l}\text { USA/ } \\
\text { African- } \\
\text { American }\end{array}$ & $\begin{array}{l}4 \text { months/ } \\
\text { N/A }\end{array}$ & $\begin{array}{l}\text { scalp, occipital area/ } \\
11 \times 4 \mathrm{~cm}\end{array}$ & $\begin{array}{l}\text { biopsy, normal thyroid } \\
\text { level }\end{array}$ & $\begin{array}{l}\text { topical } \\
\text { steroid }\end{array}$ \\
\hline Cho and Lee [7], 2007 & $\begin{array}{l}\text { female/ } \\
17 \text { years }\end{array}$ & $\begin{array}{l}\text { Korea/ } \\
\text { Asian }\end{array}$ & $\begin{array}{l}1 \text { year/ } \\
\text { N/A }\end{array}$ & $\begin{array}{l}\text { left eyebrow, } \\
\text { eyelashes }\end{array}$ & $\begin{array}{l}\text { biopsy, autoantibodies } \\
\text { positive }\end{array}$ & N/A \\
\hline Yadav et al. [8], 2009 & $\begin{array}{l}\text { female/ } \\
12 \text { years }\end{array}$ & $\begin{array}{l}\text { India/ } \\
\text { Asian }\end{array}$ & $\begin{array}{l}1 \text { month/ } \\
\text { N/A }\end{array}$ & $\begin{array}{l}\text { left eyelid, eyelashes/ } \\
15 \times 4 \mathrm{~mm}\end{array}$ & eye examination normal & $\begin{array}{l}\text { prostaglandin } \\
\text { E2 topical }\end{array}$ \\
\hline Ramot et al. [9], 2010 & $\begin{array}{l}\text { female/ } \\
60 \text { years }\end{array}$ & $\begin{array}{l}\text { Israel/ } \\
\mathrm{N} / \mathrm{A}\end{array}$ & $\begin{array}{l}2 \text { weeks/ } \\
\text { N/A }\end{array}$ & $\begin{array}{l}\text { scalp, vertex/ } \\
\text { a few centimeters }\end{array}$ & $\begin{array}{l}\text { biopsy, hypothyroidism, } \\
\text { hypercholesterolemia }\end{array}$ & $\mathrm{N} / \mathrm{A}$ \\
\hline $\begin{array}{l}\text { Rodriguez-Martin et al. } \\
{[10], 2010}\end{array}$ & $\begin{array}{l}\text { female/ } \\
53 \text { years }\end{array}$ & $\begin{array}{l}\text { Spain/ } \\
\text { Caucasian }\end{array}$ & $\begin{array}{l}2 \text { years/ } \\
\text { vitiligo preceded } \\
\text { alopecia }\end{array}$ & whole scalp & $\begin{array}{l}\text { biopsy, hyperthyroidism, } \\
\text { anxiety disorder }\end{array}$ & N/A \\
\hline $\begin{array}{l}\text { Ozcan and Cevlik Aydoğan } \\
{[11], 2012}\end{array}$ & $\begin{array}{l}\text { male/ } \\
8 \text { years }\end{array}$ & $\begin{array}{l}\text { Turkey/ } \\
\text { Caucasian }\end{array}$ & $\begin{array}{l}1 \text { month/ } \\
\text { both at the same time }\end{array}$ & $\begin{array}{l}\text { scalp, frontal area/ } \\
4 \times 2.5 \mathrm{~cm}\end{array}$ & $\begin{array}{l}\text { biopsy, blood sugar, } \\
\text { thyroid function normal }\end{array}$ & N/A \\
\hline $\begin{array}{l}\text { Krishnaram et al. [12], } \\
2013\end{array}$ & $\begin{array}{l}\text { male/ } \\
42 \text { years }\end{array}$ & $\begin{array}{l}\text { India/ } \\
\text { Asian }\end{array}$ & $\begin{array}{l}2 \text { months/ } \\
\text { alopecia preceded } \\
\text { vitiligo }\end{array}$ & $\begin{array}{l}\text { scalp, frontal area/ } \\
11 \times 6 \text { and } 4 \times 3 \mathrm{~cm}\end{array}$ & $\begin{array}{l}\text { biopsy, CBC, } \\
\text { chemistry and thyroid } \\
\text { normal }\end{array}$ & $\begin{array}{l}\text { topical } \\
\text { steroid }\end{array}$ \\
\hline
\end{tabular}




\section{Case Reports in Dermatology}

\begin{tabular}{l|l}
\hline Case Rep Dermatol 2013;5:225-231 \\
\hline DOI: 10.1159/000354767 & $\begin{array}{l}\text { (c) 2013 S. Karger AG, Basel } \\
\text { www.karger.com/cde }\end{array}$ \\
\hline
\end{tabular}

Riad et al.: Diphenylcyclopropenone-Induced Vitiligo in a Patient with Alopecia Universalis

Table 2. Studies published for DCP-induced vitiligo in patients with alopecia areata

\begin{tabular}{|c|c|c|c|c|c|c|}
\hline Author, year & $\begin{array}{l}\text { Sex/ } \\
\text { age }\end{array}$ & $\begin{array}{l}\text { Country/ } \\
\text { race }\end{array}$ & $\begin{array}{l}\text { Site/ } \\
\text { size of alopecia }\end{array}$ & $\begin{array}{l}\text { Induction } \\
\text { duration/ } \\
\text { DCP concentration }\end{array}$ & $\begin{array}{l}\text { Site/ } \\
\text { size of vitiligo }\end{array}$ & $\begin{array}{l}\text { Therapy/ } \\
\text { response }\end{array}$ \\
\hline $\begin{array}{l}\text { Hatzis et al. [13], } \\
1988\end{array}$ & $\begin{array}{l}1 \text { male/28 years } \\
2 \text { females } / 19 \\
\text { and } 53 \text { years }\end{array}$ & $\begin{array}{l}\text { Greece/ } \\
\text { Caucasian }\end{array}$ & extensive alopecia & $\begin{array}{l}3-5 \text { months/ } \\
0.05-0.1 \%\end{array}$ & $\begin{array}{l}\text { treated area } \\
\text { in } 1 \text { case: remote area }\end{array}$ & $\begin{array}{l}\text { topical steroid/ } \\
\text { only the male } \\
\text { improved }\end{array}$ \\
\hline $\begin{array}{l}\text { Duhra and Foulds } \\
{[14], 1990}\end{array}$ & male/37 years & $\begin{array}{l}\mathrm{UK} / \\
\mathrm{N} / \mathrm{A}\end{array}$ & $\mathrm{AT}$ & $\begin{array}{l}6 \text { weeks/ } \\
0.5 \%\end{array}$ & $\begin{array}{l}\text { tested area in forearm } \\
\text { and adjacent area in } \\
\text { nape and back }\end{array}$ & $\begin{array}{l}\text { DCP-induced hair } \\
\text { growth/ } \\
\text { other vitiligo areas } \\
\text { unchanged }\end{array}$ \\
\hline $\begin{array}{l}\text { Henderson and } \\
\text { Ilchyshyn [15], } \\
1995\end{array}$ & male/23 years & $\begin{array}{l}\text { UK/ } \\
\text { Asian }\end{array}$ & $\mathrm{AU}$ & $\begin{array}{l}13 \text { weeks/ } \\
0.1 \%\end{array}$ & $\begin{array}{l}\text { treated and adjacent } \\
\text { areas in face and neck }\end{array}$ & $\begin{array}{l}\text { topical steroid/ } \\
\text { only a weak } \\
\text { response, self- } \\
\text { improved }\end{array}$ \\
\hline $\begin{array}{l}\text { Pan et al. [16], } \\
2009\end{array}$ & $\begin{array}{l}1 \text { male } / 67 \text { years } \\
3 \text { females/12, } \\
54 \text { and } 57 \text { years }\end{array}$ & $\begin{array}{l}\text { Singapore/ } \\
\text { all Asians: } \\
2 \text { Chinese } \\
1 \text { Indian } \\
1 \text { Malay }\end{array}$ & extensive alopecia & $\begin{array}{l}10.5 \text { months/ } \\
0.0001-0.05 \%\end{array}$ & $\begin{array}{l}\text { in } 2 \text { of } 4 \text { cases: treated } \\
\text { and remote areas }\end{array}$ & $\begin{array}{l}\text { in } 3 \text { cases: NB-UVB, } \\
\text { in } 1 \text { case: topical } \\
\text { PUVA/ } \\
\text { in } 3 \text { cases: a good } \\
\text { response }\end{array}$ \\
\hline $\begin{array}{l}\text { Pires et al. [17], } \\
2010\end{array}$ & male/30 years & $\begin{array}{l}\text { Brazil/ } \\
\text { Caucasian }\end{array}$ & $\begin{array}{l}\text { multiple patches on } \\
\text { scalp, beard and } \\
\text { eyelashes }\end{array}$ & $\begin{array}{l}5 \text { months/ } \\
0.02 \% \\
\text { on patch-test site: } \\
30 \text { days }\end{array}$ & $\begin{array}{l}\text { treated and tested } \\
\text { areas }\end{array}$ & $\begin{array}{l}\text { topical steroid/ } \\
\text { no response }\end{array}$ \\
\hline $\begin{array}{l}\text { Ganzetti et al. [18], } \\
2010\end{array}$ & male/34 years & $\begin{array}{l}\text { Italy/ } \\
\text { Caucasian }\end{array}$ & extensive alopecia & $\begin{array}{l}9 \text { months/ } \\
0.5 \%\end{array}$ & $\begin{array}{l}\text { treated and remote } \\
\text { areas }\end{array}$ & $\begin{array}{l}\text { NB-UVB/ } \\
\text { a good response }\end{array}$ \\
\hline $\begin{array}{l}\text { Nilforoushzadeh } \\
\text { et al. [19], } 2012\end{array}$ & $\begin{array}{l}1 \text { male } / 37 \text { years } \\
1 \text { female } / 42 \text { years }\end{array}$ & $\begin{array}{l}\text { Iran/ } \\
\text { Caucasian }\end{array}$ & $\begin{array}{l}\text { male: AT } \\
\text { female: scattered } \\
\text { areas }\end{array}$ & $\begin{array}{l}3-5 \text { months/ } \\
0.5 \%\end{array}$ & remote areas & $\begin{array}{l}\text { male: N/A } \\
\text { female: vitiligo } \\
\text { remained unchanged }\end{array}$ \\
\hline Our study & male/52 years & $\begin{array}{l}\text { Qatar/ } \\
\text { Caucasian }\end{array}$ & $\mathrm{AU}$ & $\begin{array}{l}6 \text { months/ } \\
0.01 \%\end{array}$ & $\begin{array}{l}\text { treated areas, a few } \\
\text { scattered patches }\end{array}$ & $\begin{array}{l}\text { responded well to } \\
\text { pulse steroid and to a } \\
\text { lesser extent to } \\
\text { excimer laser }\end{array}$ \\
\hline
\end{tabular}




\section{Case Reports in Dermatology}

Riad et al.: Diphenylcyclopropenone-Induced Vitiligo in a Patient with Alopecia Universalis
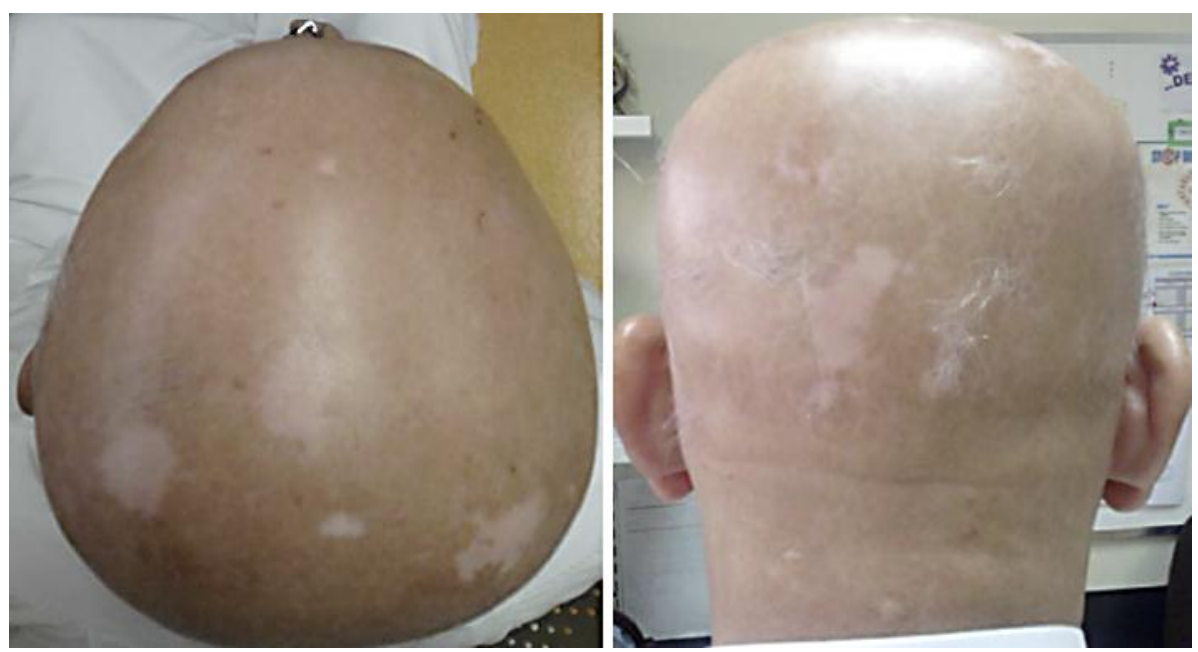

Fig. 1. Photographs of the AU patient after the appearance of patches of vitiligo attributable to the application of DCP.
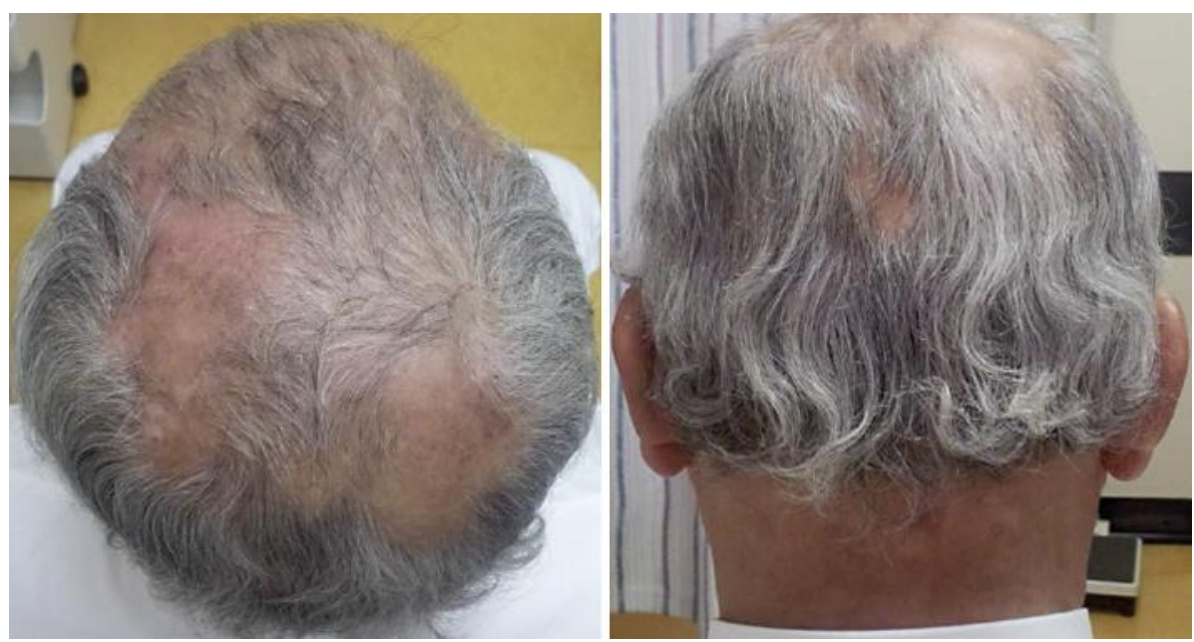

Fig. 2. Photographs of the patient after therapy; notice the regrowth of hair and repigmentation of vitiligo in most of the affected areas. 